\title{
Sex differences in the generalization of fear as a function of retention intervals
}

\author{
Joseph Lynch III, ${ }^{1}$ Patrick K. Cullen, Aaron M. Jasnow, and David C. Riccio
}

Department of Psychology, Kent State University, Kent, Ohio 44242, USA

\begin{abstract}
In previous studies using male rodents, context change disrupted a fear response at a short, but not a long, retention interval. Here, we examined the effects of context changes on fear responses as a function of time in male and female rats. Males displayed context discrimination at all intervals, whereas females exhibited generalization by $5 \mathrm{~d}$. Ovariectomized females with no hormone replacement displayed context discrimination at $5 \mathrm{~d}$, whereas those receiving $17 \beta$-estradiol generalized their fear response to a neutral context. These results demonstrate that fear generalization for contextual cues occurs faster in female rats and is mediated, in part, by estrogens.
\end{abstract}

Anxiety disorders are the most prevalent mental disorder in the US (Kessler et al. 2005). More specifically, females are 60\% more likely than males to be diagnosed with an anxiety disorder (Kessler et al. 1994; Wang et al. 2005) and the exact cause of this sex difference is unknown. For example, post-traumatic stress disorder (PTSD) is one specific anxiety disorder with a higher prevalence rate in females (Kessler et al. 1995; Olff et al. 2007). PTSD is marked by the persistence of fear and anxiety and the tendency to generalize fear to neutral cues and contexts (Grillon and Morgan 1999; Brewin 2001). These symptoms are possibly due to deficits in discriminatory fear learning (Grillon and Morgan 1999; Jovanovic et al. 2009, 2010) or the result of hyperarousal associated with anxiety disorders (Archer 1974; Bartolini et al. 1987; Armstrong and Hille 1998).

Studies of fear generalization with animals have demonstrated that a learned fear response is context-dependent; fear responses are significantly attenuated when testing occurs at a short interval (e.g., $1 \mathrm{~d}$ after training) in a neutral context (i.e., the context shift effect). However, when rodents are tested at long delays after training (e.g., $14 \mathrm{~d}$ after training), the context shift effect is eliminated; rodents freeze equivalently to the training and the neutral context (Riccio et al. 1984; Zhou and Riccio 1996; Biedenkapp and Rudy 2007; Wiltgen and Silva 2007). Over time, rodents generalize their fear response to neutral contexts. For example, Zhou and Riccio (1996) trained male rats in passive avoidance and tested 1 or $14 \mathrm{~d}$ after training in the same context as training or a neutral context. At $1 \mathrm{~d}$, rats tested in the neutral context display little or no avoidance, whereas those tested in the same context demonstrate high levels of avoidance (i.e., the context shift effect). However, $14 \mathrm{~d}$ after training, the groups tested in a neutral context had performance comparable to the group in the same (training) context (Zhou and Riccio 1996). This effect has been replicated by several labs (for review, see Jasnow et al. 2012).

In recent years, several hypotheses have been developed to explain the phenomenon of fear generalization in animal models. Hippocampal-dependent memory, such as memory for context, undergoes a transfer from short-term hippocampal stores to more long-term cortical stores, a process known as systems consolidation (Kim and Fanselow 1992; Anagnostaras et al. 2001; Wiltgen et al. 2006; Jasnow et al. 2012). When the memory is transferred, the original memory trace is transformed from a

\footnotetext{
${ }^{1}$ Corresponding author

E-mail jlynch22@kent.edu

Article is online at http://www.learnmem.org/cgi/doi/10.1101//m.032011.113.
}

context-specific hippocampal-dependent memory to a hippocampal-independent cortical memory that lacks context specificity (Winocur et al. 2009). Brain scans in humans during memory retrieval show differential activation of the hippocampus and prefrontal cortex (PFC) for newly acquired memories versus older memories. New memories have high hippocampal activation and low activation of the PFC, whereas older memories have low hippocampal activation and high PFC activation (Bontempi et al. 1999; Frankland et al. 2004; Maviel et al. 2004). The differences in activation are mirrored in studies assessing the effects of lesions of the hippocampus; lesions directly after training eliminate the context shift effect at short intervals. However, when the hippocampal lesions are delayed, performance is not affected in either context, suggesting the hippocampus is only required when the memory is still context-dependent or precise (Winocur et al. 2007, 2009; Wiltgen et al. 2010). Therefore, the hippocampus may be involved in processing a memory as long as that memory remains context-dependent. However, no evidence to date has examined whether this transformation hypothesis differs between males and females.

Differences in fear and anxiety between males and females have been well established in both humans and nonhuman animals (Archer 1975; Stewart et al. 1997; Frye et al. 2000; Zorawski et al. 2005; Stark et al. 2006). In addition, a wealth of evidence demonstrates that estrogens play a major role in sex differences in behavior and that estrogens act directly on the hippocampus to affect synaptic plasticity and learning and memory (Beatty and Beatty 1970; Frye et al. 2000; Li et al. 2004; Baufreton et al. 2005; González-Burgos et al. 2005; Bekker and van MensVerhulst 2007; Biedenkapp and Rudy 2007; Liu et al. 2008; Arias et al. 2009). Thus, estrogens may mediate differences in memory generalization between males and females, although this has not yet been examined. A serendipitous finding in our lab found that male rats exhibited a context shift effect $5 \mathrm{~d}$ after training, whereas females exhibited high levels of avoidance in either context (PK Cullen, L Pickens, SF Fountain, DC Riccio, in prep.). The present study investigated sex differences in fear generalization more systematically. In each experiment, animals were trained in passive

(C) 2013 Lynch et al. This article is distributed exclusively by Cold Spring Harbor Laboratory Press for the first 12 months after the full-issue publication date (see http://learnmem.cshlp.org/site/misc/terms.xhtml). After 12 months, it is available under a Creative Commons License (Attribution-NonCommercial 3.0 Unported), as described at http:// creativecommons.org/licenses/by-nc/3.0/. 
avoidance and then tested at different retention intervals in the same context as training or a neutral context. First, we established a temporal gradient of fear generalization for male and female rats across different retention intervals. Second, we examined the role of estrogens on the generalization of fear by testing ovariectomized (OVX) female rats given Silastic capsule implants containing $17 \beta$-estradiol.

Analyses of latency-to-cross scores at training revealed no significant differences $(P>0.09)$. At $1 \mathrm{~d}$ (Fig. 1A), the main effect of context was significant $\left(F_{(1,42)}=50.309, P<0.001\right)$, but the main effect of $\operatorname{sex}\left(F_{(1,42)}=0.556\right.$, ns) and the interaction between context and sex was not significant $\left(F_{(1,42)}=0.005\right.$, ns). Although the interaction term was not significant, we were interested in differences between males tested in the same or neutral context, females tested in the same or neutral context, and males and females tested in the neutral context. Therefore, independent $t$-tests were conducted for those direct comparisons at all retention intervals. Latency-to-cross scores for Male-Same vs. Male-Neutral $\left(t_{(20)}=5.432, P<0.001\right)$ and Female-Same vs. Female-Neutral were significantly different $\left(t_{(22)}=4.765, P<0.001\right)$. In addition, Male-Neutral and Female-Neutral did not differ $\left(t_{(21)}=0.569\right.$, ns). Thus, a change in context attenuated avoidance, regardless of sex, at $1 \mathrm{~d}$.

At $3 \mathrm{~d}$ (Fig. 1B), the main effect of context was significant $\left(F_{(1,41)}=31.140, P<0.001\right)$, the main effect of sex was nonsignificant $\left(F_{(1,41)}=0.174, \mathrm{~ns}\right)$, and the interaction between context and sex was nonsignificant $\left(F_{(1,41)}=3.066, \mathrm{~ns}\right)$. Male-Same vs. Male-Neutral were significantly different $\left(t_{(19)}=5.974, \quad P<\right.$ $0.001)$ as were Female-Same vs. Female-Neutral $\left(t_{(22)}=2.504\right.$, $P<0.05)$. In addition, Male-Neutral vs. Female-Neutral were not significantly different $\left(t_{(21)}=1.262\right.$, ns). These results demonstrate that males and females continued to display the context shift effect at the 3-d retention interval.
At $5 \mathrm{~d}$ (Fig. 1C), the main effects for context $\left(F_{(1,37)}=26.550\right.$, $P<0.001)$, sex $\left(F_{(1,37)}=15.504, P<0.001\right)$, and the interaction between context and sex $\left(F_{(1,37)}=4.839, P<0.05\right)$ were significantly different. Male-Same vs. Male-Neutral $\left(t_{(17)}=4.38, P<\right.$ $0.001)$, Female-Same vs. Female-Neutral $\left(t_{(20)}=2.528, P<0.05\right)$, Male-Neutral vs. Female-Neutral were significantly different $\left(t_{(16)}=3.837, P<0.001\right)$. These results demonstrate that females did not display complete generalization to the neutral context at $5 \mathrm{~d}$. However, females did display higher latencies compared to males in the neutral context, suggesting that females begin to generalize fear responses to the neutral context at an earlier time point compared to males.

At $7 \mathrm{~d}$ (Fig. 1D), the main effects for context $\left(F_{(1,42)}=13.075\right.$, $P<0.001)$ and sex $\left(F_{(1,42)}=9.26, P<0.01\right)$ were significant. However, the interaction between context and sex was nonsignificant $\left(F_{(1,42)}=2.603, n s\right)$. Male-Same vs. Male-Neutral were significantly different $\left(t_{(20)}=3.504, P<0.01\right)$. However, Female-Same vs. Female-Neutral were not significantly different $\left(t_{(22)}=0.149\right.$, ns). In addition, Male-Neutral vs. Female-Neutral were significantly different $\left(t_{(21)}=3.416, P<0.01\right)$. Therefore, these data suggest that females generalized fear responses to the neutral context at an earlier time point than males.

Overall, these data suggest that, although females can perceive the contextual differences at short retention intervals, they tend to generalize fear to neutral contextual cues at a shorter retention interval than males. Females had significantly higher latencies in the neutral context compared to males at the 5 and $7 \mathrm{~d}$ retention intervals, displaying complete fear generalization by the 7-d interval.

To determine if differences in fear generalization were mediated by estrogens, adult female rats were ovariectomized (OVX) and half were given a Silastic capsule containing $17 \beta$-estradiol and the other half received an empty capsule and tested for fear generalization at 1,5 , or $7 \mathrm{~d}$. Analyses of latency-to-cross scores at training revealed no significant differences $(P>$ 0.29). At $1 \mathrm{~d}$ (Fig. $2 \mathrm{~A}$ ), the main effect of context was significant $\left(F_{(1,39)}=11.08\right.$, $P<0.01)$, but not the main effect of hormone $\left(F_{(1,39)}=0.562, \mathrm{~ns}\right)$. The interaction between context and hormone was also nonsignificant $\left(F_{(1,39)}=0.049\right.$, ns). OVX-C Same vs. OVX-C Neutral $\left(t_{(17)}=\right.$ 2.105, $P<0.05)$ and OVX-ES Same vs. OVX-ES Neutral $\left(t_{(22)}=2.647, P<0.05\right)$ were significantly different and OVX-C Neutral vs. OVX-ES Neutral were not significantly different $\left(t_{(19)}=0.598\right.$, ns). Thus, $1 \mathrm{~d}$ after training, ovariectomized females displayed a significant context shift effect, exhibiting less fear in the neutral context, regardless of estrogen treatment.

At $5 \mathrm{~d}$ (Fig. 2B), the main effect of context was significant $\left(F_{(1,43)}=9.039\right.$, $P<0.01)$. The main effect for hormone $\left(F_{(1,43)}=0.305\right.$, ns) and the interaction between context and hormone $\left(F_{(1,43)}=\right.$ 0.969, ns) were not significant. OVX-C Same vs. OVX-C Neutral were significantly different $\left(t_{(22)}=3.059, P<0.01\right)$. However, OVX-ES Same vs. OVX-ES Neutral were not $\left(t_{(21)}=1.327\right.$, ns). The latency scores for OVX-C Neutral vs. OVXES Neutral were nonsignificant $\left(t_{(22)}=\right.$ $0.950, \mathrm{~ns})$. Therefore, the generalization 
$\mathbf{A}$

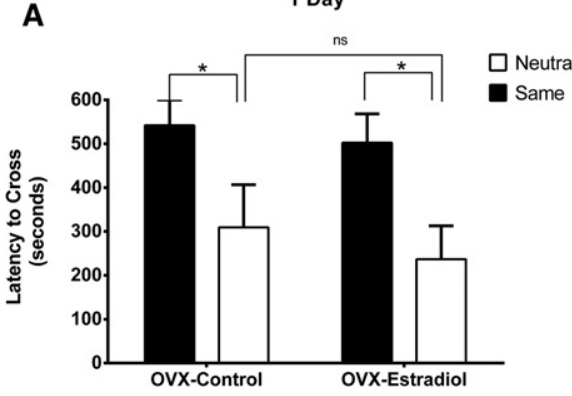

B

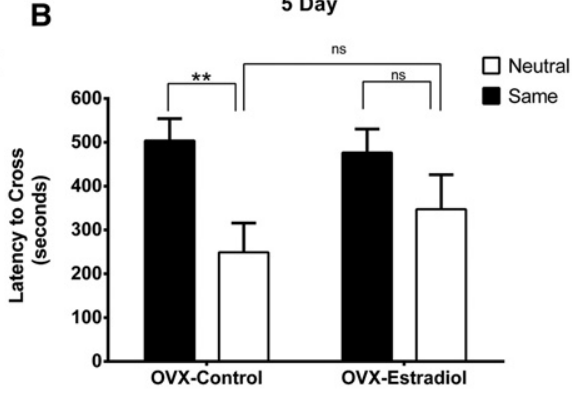

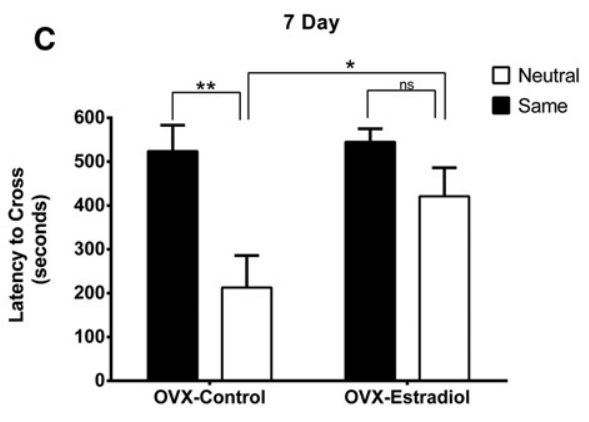

Figure 2. Mean ( \pm SEM) latency-to-cross in seconds. (A) Both groups display significant context discrimination at $1 \mathrm{~d}$, regardless of estradiol treatment. $(B)$ OVX-C females display significant context discrimination whereas OVX-ES females do not. However, no significant difference between the groups tested in the neutral context at $5 \mathrm{~d}$ is seen. (C) Only females receiving no estradiol display context discrimination at $7 \mathrm{~d}$. Those females receiving $17 \beta$-estradiol replacement demonstrated context generalization and higher fear in the neutral context compared to OVX-C females. Significant differences were ascribed at $\left(^{*}\right) P<0.05,\left({ }^{*}\right) P<0.01$.

observed in OVX-ES at the 5-d retention interval was not significantly greater than that for OVX-C animals.

At $7 \mathrm{~d}$, the main effect for context was significant $\left(F_{(1,36)}=\right.$ 13.627, $P<0.001)$. The main effect for hormone treatment was nonsignificant by the conventional standards of $P<0.05$, although it approached significance $\left(F_{(1,36)}=3.779, P=0.060\right)$. The interaction between context and hormone replacement was also nonsignificant $\left(F_{(1,36)}=2.508, n s\right)$. OVX-C Same vs. OVX-C Neutral were significantly different $\left(t_{(18)}=3.319, P<0.01\right)$. In contrast, OVX-ES Same vs. OVX-ES Neutral were not significantly different $\left(t_{(18)}=1.736\right.$, ns). Comparison of OVX-C Neutral vs. OVX-ES Neutral was significantly different $\left(t_{(18)}=2.128, P<\right.$ $0.05)$. Thus, ovariectomized females given $17 \beta$-estradiol demonstrated significant fear generalization as evidenced by similar latency-to-cross scores in either context and also show significantly longer latencies in the neutral context compared to females given no estrogen following ovariectomy.

Taken together, these data suggest that fear generalization in female rodents is regulated, in part, by estrogens. Alternative explanations for the sex differences in fear generalization, such as differences in exploratory behavior (Archer 1974), differential rates of acquisition in passive avoidance (Denti and Epstein 1972), and shock sensitivity (Snowdon et al. 1964; Beatty and Beatty 1970; Blizard 1971), can be ruled out due to intact males and females displaying equivalent behavioral responses at $1 \mathrm{~d}$, as indicated by the context shift effect. Similarly, the context shift effect exhibited by both OVX-C and OVX-ES at $1 \mathrm{~d}$ suggests that neither surgery nor capsule implantation had a negative impact on passive avoidance acquisition or the ability to discriminate contextual cues at a short interval. One potential issue with our findings is the use of a 10-min time limit at test, which may have generated an arbitrary ceiling effect. However, such cut-off times are a standard in the field and we do not believe that the results of the present study are due to an arbitrary ceiling effect.

To the best of our knowledge, our findings are the first to show sex differences in fear generalization. Several studies demonstrate estrogenic effects on fear and anxiety in both human and nonhuman animals. For example, naturally cycling women with high estrogen levels demonstrate better extinction retention than those with low estrogen levels (Milad et al. 2010). In animals, extinction retention is facilitated by high levels of estrogens (Milad et al. 2009) and this effect may be regulated via estradiol actions on the hippocampus (Chang et al. 2009). Similarly, the hippocampus plays an important role in the generalization of fear (Ruediger et al. 2011). Estrogens may act upon ER $\alpha$ and ER $\beta$ in the CA3 region (Azcoitia et al. 1999; Shughrue and Merchenthaler 2000; Milner et al. 2005) to modulate the connections made between the CA3 and CA1 regions by increasing the ability of CA3 neurons to synchronize with CA1 targets (Woolley et al. 1998; Yankova et al. 2001). Indeed, the presence of estrogens results in increased apical dendritic spines within the CA1 (Gould et al. 1990; Woolley et al. 1990, 1998; Woolley and McEwen 1993; McEwen et al. 1995). Thus, estrogens may act directly on hippocampal regions to modulate contextual memory storage, resulting in alteration in the generalization of fear responses to neutral contexts. Taken together, the present data suggest that estrogens may modulate the transfer of contextual memories to neocortical sites from the hippocampus, resulting in fear generalization at earlier time points in females compared to males. These findings potentially underlie the greater incidence of PTSD in females than in males, as the more rapid loss of precision of contextual memory impairs the compartmentalization of feareliciting cues ordinarily afforded by different contexts.

Male and female adult Long-Evans rats $\sim 90 \mathrm{~d}$ old were used for all experiments $(n=8-12)$. A week prior to beginning the experiment, animals were individually housed and were maintained on a 14/10-hr light/dark cycle. Food and water were available ad libitum throughout the experiment. All animal procedures were carried out in accordance with Kent State University Institutional Animal Care and Use (IACUC) guidelines.

For all experiments, the training and testing apparatus were two identical $43.18 \times 17.78 \times 17.78$-cm shuttle boxes placed on grid floors. The boxes were comprised of two chambers of equal size-one black and one white-that were divided by a guillotine door. Each box was placed in one of two distinct contexts. Context A was a $1.6 \times 2.33$-m room with house fluorescent lights and contained bare white walls and no artificial scents or sounds; Context $B$ was a $1.83 \times 2.74-\mathrm{m}$ room that was lit by a $25-\mathrm{W}$ red light bulb with posters on the walls. Context B had white noise $(70 \mathrm{db})$ and artificial scent via a Glade Plug-Ins Scented Oil Country Berry air freshener at all times. In each context, the experimenter wore a different glove (rubber dish glove in A; vinyl lab glove in B) to handle the rat.

Prior to training, animals were handled for 5 min on two consecutive days. For training, animals were brought to Context A, 
held on the experimenter's hand for $30 \mathrm{sec}$ and placed on the white side of the shuttle box. The door was raised after $20 \mathrm{sec}$ and the initial latency to cross into the black compartment (all four paws) was recorded. Upon crossing, the guillotine door was lowered and two nonescapable 1-sec, $0.6-\mathrm{mA}$ scrambled footshocks were delivered $5 \mathrm{sec}$ apart by a constant current AC shock generator (Model 5806, Lafayette Instruments). Ten seconds after receiving the second footshock, the animal was removed from the chamber and returned to the main colony. Animals with a latency to cross longer than $100 \mathrm{sec}$ during training $-<1 \%$ of the animals-were removed from the final analysis (e.g., Zarrindast et al. 2002, 2005; Ahmadi et al. 2007a,b; Khakpai et al. 2012).

For testing, rats were brought back into the experimental room at 1, 3, 5, or $7 \mathrm{~d}$ after training. Half of the rats were tested in Context A (same) and half in Context B (neutral). The test procedure was identical to training except that the guillotine door remained open for $600 \mathrm{sec}$ and no shocks were delivered. The initial latency to cross was recorded as the dependent measure. After a total of $600 \mathrm{sec}$ had elapsed, the rat was removed and returned to the main colony.

In the second experiment, female rats were anesthetized with isoflurane and received a $5 \mathrm{mg} / \mathrm{kg}$ dose of ketoprofen $5 \mathrm{~min}$ before bilateral ovariectomy through a dorsal incision. After removal of the ovaries, the incision was sutured using surgical staples and a Silastic capsule containing $17 \beta$-estradiol or an empty capsule was inserted behind the shoulder blades of the animal. The Silastic (polydimethylsiloxane) implants were constructed from Silastic tubing (i.d. 0.078 in, o.d. $0.125 \mathrm{in}$ ) cut to a 5-mm length. Each end was filled with Factor II medical adhesive $1 \mathrm{~mm}$ in length. The hormone was packed into the remaining 3-mm length, which has been shown to produce levels of $\sim 30-40 \mathrm{pg} /$ mL of estradiol (Bridges 1984; Hiroi and Neumaier 2006). Before implantation, capsules were incubated in saline for $24 \mathrm{~h}$ at $37^{\circ} \mathrm{C}$. Animals were handled $7 \mathrm{~d}$ following surgery and began training $9 \mathrm{~d}$ after surgery. Animals were tested 1,5 , or $7 \mathrm{~d}$ after training in either the same context or a neutral context. Animals were split into groups based on the retention interval of test and separate two-way ANOVAs were conducted at each retention interval for both experiments. To make direct comparisons, independent $t$-tests were conducted.

\section{Acknowledgments}

Partial funding of this research was provided by a Kent State GSS Research Award. We thank Jeremy Meduri for helpful comments on the manuscript and acknowledge the helpful contributions of Maeson Latsko, Dina Dejanovic, Adam Ulmen, and Tyler Vanderhoof to this project.

\section{References}

Ahmadi S, Zarrindast MR, Haeri-Rohani A, Rezayof A, Nouri M. 2007a. Nicotine improves morphine-induced impairment of memory: Possible involvement of $N$-methyl-D-aspartate receptors in the nucleus accumbens. Dev Neurobiol 67: 1118-1127.

Ahmadi S, Zarrindast MR, Nouri M, Haeri-Rohani A, Rezayof A. 2007b. $\mathrm{N}$-Methyl-D-aspartate receptors in the ventral tegmental area are involved in retrieval of inhibitory avoidance memory by nicotine. Neurobiol Learn Mem 88: 352-358.

Anagnostaras SG, Gale GD, Fanselow MS. 2001. Hippocampus and contextual fear conditioning: Recent controversies and advances. Hippocampus 11: 8-17.

Archer J. 1974. Sex differences in the emotional behavior of three strains of laboratory rat. Learn Behav 2: 43-48.

Archer J. 1975. Rodent sex differences in emotional and related behavior. Behav Biol 14: 451-479.

Arias C, Zepeda A, Hernández-Ortega K, Leal-Galicia P, Lojero C, Camacho-Arroyo I. 2009. Sex and estrous cycle-dependent differences in glial fibrillary acidic protein immunoreactivity in the adult rat hippocampus. Horm Behav 55: 257-263.
Armstrong CM, Hille B. 1998. Voltage-gated ion channels and electrical excitability. Neuron 20: 371-380.

Azcoitia I, Sierra A, Miguel Garcia-Segura L. 1999. Localization of estrogen receptor $\beta$-immunoreactivity in astrocytes of the adult rat brain. Glia 26: $260-267$.

Bartolini A, Galli A, Ghelardini C, Giotti A, Malcangio M, MalmbergAiello P, Zucchi PL. 1987. Antinociception induced by systemic administration of local anaesthetics depends on a central cholinergic mechanism. Br J Pharmacol 92: 711-721.

Baufreton J, Atherton JF, Surmeier DJ, Bevan MD. 2005. Enhancement of excitatory synaptic integration by GABAergic inhibition in the subthalamic nucleus. J Neurosci 25: 8505-8517.

Beatty WW, Beatty PA. 1970. Hormonal determinants of sex differences in avoidance behavior and reactivity to electric shock in the rat. J Comp Physiol Psychol 73: 446-455.

Bekker MHJ, van Mens-Verhulst J. 2007. Anxiety disorders: Sex differences in prevalence, degree, and background, but gender-neutral treatment. Gend Med 4 (Suppl 2): S178-S193.

Biedenkapp JC, Rudy JW. 2007. Context preexposure prevents forgetting of a contextual fear memory: Implication for regional changes in brain activation patterns associated with recent and remote memory tests. Learn Mem 14: 200-203.

Blizard DA. 1971. Autonomic reactivity in the rat: Effects of genetic selection for emotionality. J Comp Physiol Psychol 76: 282-289.

Bontempi B, Laurent-Demir C, Destrade C, Jaffard R. 1999. Time-dependent reorganization of brain circuitry underlying long-term memory storage. Nature 400: 671-675.

Brewin CR. 2001. Memory processes in post-traumatic stress disorder. Int Rev Psychiatry 13: 159-163.

Bridges RS. 1984. A quantitative analysis of the roles of dosage, sequence, and duration of estradiol and progesterone exposure in the regulation of maternal behavior in the rat. Endocrinology 114: 930-940.

Chang YJ, Yang CH, Liang YC, Yeh CM, Huang CC, Hsu KS. 2009. Estrogen modulates sexually dimorphic contextual fear extinction in rats through estrogen receptor $\beta$. Hippocampus 19: 1142-1150.

Denti A, Epstein A. 1972. Sex differences in the acquisition of two kinds of avoidance behavior in rats. Physiol Behav 8: 611-615.

Frankland PW, Bontempi B, Talton LE, Kaczmarek L, Silva AJ. 2004. The involvement of the anterior cingulate cortex in remote contextual fear memory. Science 304: 881-883.

Frye CA, Petralia SM, Rhodes ME. 2000. Estrous cycle and sex differences in performance on anxiety tasks coincide with increases in hippocampal

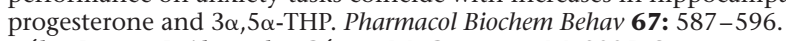

González-Burgos I, Alejandre-Gómez M, Cervantes M. 2005. Spine-type densities of hippocampal CA1 neurons vary in proestrus and estrus rats. Neurosci Lett 379: 52-54.

Gould E, Woolley CS, Frankfurt M, McEwen BS. 1990. Gonadal steroids regulate dendritic spine density in hippocampal pyramidal cells in adulthood. J Neurosci 10: $1286-1291$.

Grillon C, Morgan CA. 1999. Fear-potentiated startle conditioning to explicit and contextual cues in Gulf War veterans with posttraumatic stress disorder. J Abnorm Psychol 108: 134-142.

Hiroi R, Neumaier JF. 2006. Differential effects of ovarian steroids on anxiety versus fear as measured by open field test and fear-potentiated startle. Behav Brain Res 166: 93-100.

Jasnow AM, Cullen PK, Riccio DC. 2012. Remembering another aspect of forgetting. Front Psychol 3: 175.

Jovanovic T, Norrholm SD, Fennell JE, Keyes M, Fiallos AM, Myers KM, Davis M, Duncan EJ. 2009. Posttraumatic stress disorder may be associated with impaired fear inhibition: Relation to symptom severity. Psychiatry Res 167: 151-160.

Jovanovic T, Norrholm SD, Blanding NQ, Davis M, Duncan E, Bradley B, Ressler KJ. 2010. Impaired fear inhibition is a biomarker of PTSD but not depression. Depress Anxiety 27: 244-251.

Kessler RC, McGonagle KA, Zhao S, Nelson CB, Hughes M, Eshleman S, Wittchen HU, Kendler KS. 1994. Lifetime and 12-month prevalence of DSM-III-R psychiatric disorders in the United States. Results from the National Comorbidity Survey. Arch Gen Psychiatry 51: 8-19.

Kessler RC, Sonnega A, Bromet E, Hughes M, Nelson CB. 1995. Posttraumatic stress disorder in the National Comorbidity Survey. Arch Gen Psychiatry 52: 1048-1060.

Kessler RC, Chiu WT, Demler O, Walters EE. 2005. Prevalence, severity, and comorbidity of 12-month DSM-IV disorders in the national comorbidity survey replication. Arch Gen Psychiatry 62: 617-627.

Khakpai F, Nasehi M, Haeri-Rohani A, Eidi A, Zarrindast MR. 2012. Scopolamine induced memory impairment; possible involvement of NMDA receptor mechanisms of dorsal hippocampus and/or septum. Behav Brain Res 231: 1-10.

Kim JJ, Fanselow MS. 1992. Modality-specific retrograde amnesia of fear. Science 256: 675-677.

Li C, Brake WG, Romeo RD, Dunlop JC, Gordon M, Buzescu R, Magarinos AM, Allen PB, Greengard P, Luine V, et al. 2004. Estrogen 
alters hippocampal dendritic spine shape and enhances synaptic protein immunoreactivity and spatial memory in female mice. Proc Natl Acad Sci 101: 2185-2190.

Liu F, Day M, Muñiz LC, Bitran D, Arias R, Revilla-Sanchez R, Grauer S, Zhang G, Kelley C, Pulito V, et al. 2008. Activation of estrogen receptor- $\beta$ regulates hippocampal synaptic plasticity and improves memory. Nat Neurosci 11: 334-343.

Maviel T, Durkin TP, Menzaghi F, Bontempi B. 2004. Sites of neocortical reorganization critical for remote spatial memory. Science 305: 96-99.

McEwen BS, Gould E, Orchinik M, Weiland NG, Woolley CS. 1995. Oestrogens and the structural and functional plasticity of neurons: Implications for memory, ageing and neurodegenerative processes. In Ciba foundation symposium (ed. Bock GR, Goode JA), Vol. 191, pp. 52-73. Wiley, Chichester.

Milad MR, Igoe SA, Lebron-Milad K, Novales JE. 2009. Estrous cycle phase and gonadal hormones influence conditioned fear extinction. Neuroscience 164: 887-895.

Milad MR, Zeidan MA, Contero A, Pitman RK, Klibanski A, Rauch SL, Goldstein JM. 2010. The influence of gonadal hormones on conditioned fear extinction in healthy humans. Neuroscience 168: 652-658.

Milner TA, Ayoola K, Drake CT, Herrick SP, Tabori NE, McEwen BS, Warrier S, Alves SE. 2005. Ultrastructural localization of estrogen receptor $\beta$ immunoreactivity in the rat hippocampal formation. J Comp Neurol 491: 81-95.

Olff M, Langeland W, Draijer N, Gersons BP. 2007. Gender differences in posttraumatic stress disorder. Psychol Bull 133: 183-204.

Riccio DC, Richardson R, Ebner DL. 1984. Memory retrieval deficits based upon altered contextual cues: A paradox. Psychol Bull 96: $152-165$.

Ruediger S, Vittori C, Bednarek E, Genoud C, Strata P, Sacchetti B, Caroni P. 2011. Learning-related feedforward inhibitory connectivity growth required for memory precision. Nature 473: 514-518.

Shughrue PJ, Merchenthaler I. 2000. Evidence for novel estrogen binding sites in the rat hippocampus. Neuroscience 99: 605-612.

Snowdon CT, Bell DD, Henderson ND. 1964. Relationships between heart rate and open-field behavior. J Comp Physiol Psychol 58: $423-426$.

Stark R, Wolf OT, Tabbert K, Kagerer S, Zimmermann M, Kirsch P, Schienle A, Vaitl D. 2006. Influence of the stress hormone cortisol on fear conditioning in humans: Evidence for sex differences in the response of the prefrontal cortex. Neuroimage 32: 1290-1298.

Stewart SH, Taylor S, Baker JM. 1997. Gender differences in dimensions of anxiety sensitivity. J Anxiety Disord 11: 179-200.

Wang PS, Lane M, Olfson M, Pincus HA, Wells KB, Kessler RC. 2005. Twelve-month use of mental health services in the United States-
Results from the National Comorbidity Survey Replication. Arch Gen Psychiatry 62: 629-640.

Wiltgen BJ, Silva AJ. 2007. Memory for context becomes less specific with time. Learn Mem 14: 313-317.

Wiltgen BJ, Sanders MJ, Anagnostaras SG, Sage JR, Fanselow MS. 2006. Context fear learning in the absence of the hippocampus. J Neurosci 26: $5484-5491$.

Wiltgen BJ, Zhou M, Cai Y, Balaji J, Karlsson MG, Parivash SN, Li W, Silva AJ. 2010. The hippocampus plays a selective role in the retrieval of detailed contextual memories. Curr Biol 20: 1336-1344.

Winocur G, Moscovitch M, Sekeres M. 2007. Memory consolidation or transformation: Context manipulation and hippocampal representations of memory. Nat Neurosci 10: 555-557.

Winocur G, Frankland PW, Sekeres M, Fogel S, Moscovitch M. 2009. Changes in context-specificity during memory reconsolidation: Selective effects of hippocampal lesions. Learn Mem 16: $722-729$.

Woolley CS, McEwen BS. 1993. Roles of estradiol and progesterone in regulation of hippocampal dendritic spine density during the estrous cycle in the rat. J Comp Neurol 336: 293-306.

Woolley CS, Gould E, Frankfurt M, McEwen BS. 1990. Naturally occurring fluctuation in dendritic spine density on adult hippocampal pyramidal neurons. J Neurosci 10: 4035-4039.

Woolley CS, Wenzel HJ, Schwartzkroin PA. 1998. Estradiol increases the frequency of multiple synapse boutons in the hippocampal CA1 region of the adult female rat. J Comp Neurol 373: 108-117.

Yankova M, Hart SA, Woolley CS. 2001. Estrogen increases synaptic connectivity between single presynaptic inputs and multiple postsynaptic CA1 pyramidal cells: A serial electron-microscopic study. Proc Natl Acad Sci 98: 3525-3530.

Zarrindast MR, Eidi M, Eidi A, Oryan S. 2002. Effects of histamine and opioid systems on memory retention of passive avoidance learning in rats. Eur J Pharmacol 452: 193-197.

Zarrindast MR, Farajzadeh Z, Rostami P, Rezayof A, Nourjah P. 2005. Involvement of the ventral tegmental area (VTA) in morphine-induced memory retention in morphine-sensitized rats. Behav Brain Res 163: $100-106$.

Zhou Y, Riccio DC. 1996. Manipulation of components of context: The context shift effect and forgetting of stimulus attributes. Learn Motiv 27: 400-407.

Zorawski M, Cook CA, Kuhn CM, LaBar KS. 2005. Sex, stress, and fear: Individual differences in conditioned learning. Cogn Affect Behav Neurosci 5: 191-201.

Received June 4, 2013; accepted in revised form August 12, 2013. 


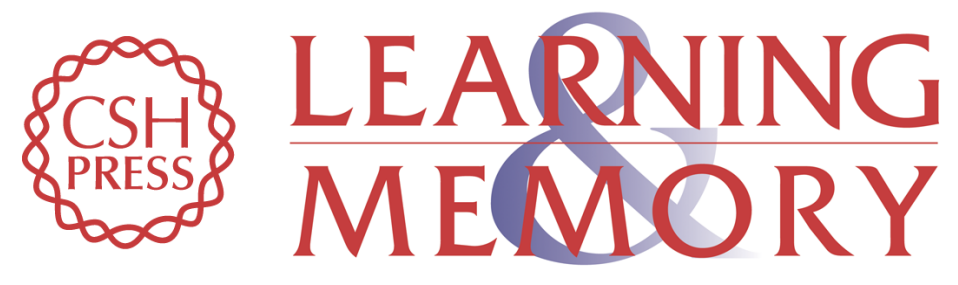

\section{Sex differences in the generalization of fear as a function of retention intervals}

Joseph Lynch III, Patrick K. Cullen, Aaron M. Jasnow, et al.

Learn. Mem. 2013, 20:

Access the most recent version at doi:10.1101/Im.032011.113

References This article cites 60 articles, 12 of which can be accessed free at:

http://learnmem.cshlp.org/content/20/11/628.full.html\#ref-list-1

Creative This article is distributed exclusively by Cold Spring Harbor Laboratory Press for the

Commons first 12 months after the full-issue publication date (see

License http://learnmem.cshlp.org/site/misc/terms.xhtml). After 12 months, it is available under a Creative Commons License (Attribution-NonCommercial 3.0 Unported), as described at http://creativecommons.org/licenses/by-nc/3.0/.

Email Alerting Receive free email alerts when new articles cite this article - sign up in the box at the Service top right corner of the article or click here. 